\title{
Efficacy of Two Inducing Agents, PG and DOM+SGNRH on the Induced Breeding of the Major Carp, Kalibaus (Labeo calbasu)
}

\author{
Abdus Salam Bhuiyan ${ }^{1}$, Jesmin Akhter ${ }^{1}$ and Syeda Mushahida-Al-Noor ${ }^{2 *}$ \\ ${ }^{1}$ Department of Zoology, Faculty of Life and Earth Science, University of Rajshahi, Rajshahi - 6205, Bangladesh \\ ${ }^{2}$ Department of Fisheries, Faculty of Agriculture, University of Rajshahi, Rajshahi - 6205, Bangladesh \\ *E-mail: munianoor@gmail.com
}

Received: 15.05.2013, Accepted: 17.06.2013

\begin{abstract}
The present study was conducted to compare the efficacy of two inducing agents PG and $\mathrm{DOM}+\mathrm{SGnRH}$ on the induced breading of Labeo calbasu. Three breeding trials were done with PG hormone as treatment 1 and three breeding trials were done with DOM + SGnRH as treatment 2. Total 8 pairs of brood fishes were collected from the Halda River and from the Jamuna River and reared in the pond, providing special diet up to their maturation. In case of treatment 1 , the females were injected $1.5 \mathrm{mg} \mathrm{PG} / \mathrm{kg}$ body weight as initial dose and $6 \mathrm{mg} \mathrm{PG} / \mathrm{kg}$ body weight as resolving dose. On the other hand, males were administered at the rate of $1.5 \mathrm{mg} \mathrm{PG} / \mathrm{kg}$ body weight. On the contrary in case of treatment 2 , the females and males were injected DOM+SGnRH at the rate of $12 \mathrm{mg} / \mathrm{kg}$ body weight and $3 \mathrm{mg} / \mathrm{kg}$ body weight respectively. In case of treatment 1 , the intervals between initial and resolving dose were 5 hours and ovulation took place within 6 hours after the resolving doses. In case of treatment 2, only initial dose is required and ovulation occurred respectively within 7 hours. The mean rates of ovulation, fertilization and hatching were 100, 77.36 and $74.5 \%$, respectively in treatment 1 . The mean rates of ovulation, fertilization and hatching were $83.33,63.83$ and $59.66 \%$, respectively in treatment 2 .
\end{abstract}

Key words: Inducing agents, Hatchery, Ovulation rate, Hatching rate, Bangladesh

\section{Introduction}

Induced spawning refers to a process in which some stimulants, hormones or pituitary extracts are injected in the brood fishes, which do not spawn in the closed water bodies, causing the fishes to spawn (Bhuiyan et al., 2007). Induced spawning of local carps through hypophysation became a common practice in Bangladesh since 1967 (Ali, 1967). Meanwhile a large number of hatcheries in the private sector have been established with the introduction of artificial breeding of exotic species (Ali, 1998).
Induced spawning has opened the door of new era in the production of fish throughout the world. In Bangladesh, successful induced spawning was first done by Ali (1967) in carps through hypophysation having been standardized later on (Haque, 1975; Islam and Chowdhury, 1976; Ahmed, 1983; Alam, 1983). The knowledge of artificial breeding is a key aspect as it permits intensive production of a given species in controlled conditions. This allows the continuation of the production of 
Abdus Salam Bhuiyan, Jesmin Akhter and Syeda Mushahida-Al-Noor / Our Nature (2013), 11(1): $17-24$

juveniles for restocking natural or artificial water bodies (Montchowui et al., 2011).

Induced breeding of captive fishes may be approached in two ways, hormonal and environmental (Marte, 1989). Artificial reproduction has been one of the bottlenecks because it has not been possible to reproduce wild cyprinids in hatchery conditions without hormonal stimulation (Krejszeff et al., 2008; Kucharczyk et al., 2008; Targońska et al., 2008; Żarski et al., 2009). For this reason, many hormonal treatments such as carp pituitary homogenate (CPE), human chorionic gonadotropin (HCG) or different luteinizing hormones have been used for stimulation of gamete maturation in commercial cyprinid culture (Brzuska, 2005; Kucharczyk et al., 2005; Krejszeff et al., 2008). A number of successful studies conducted in breeding various species of cultured fish in China with LH-RH analogues ( $\mathrm{RH}+$ Dopamine antagonist) led to the development of "Linpe method" (Peter et al., 1988).

Previously, several researchers have observed the effect of several inducing agents on different cultured carp species. Singh et al. (2000) worked on the effect of ovaprim on the induced breeding of Labeo rohita and Catla catla. Sharma and Singh (2002) observed the effect of Dopamin antagonist $+\mathrm{GnRH}$ and $\mathrm{CPE}$ on the induced breeding of Labeo rohita, Cirrhina mrigala and Catla catla.

Labeo calbasu (Hamilton) locally called "Kalibaus" is an indigenous, endangered fish in Bangladesh (IUCN, 2000). It is well known that Labeo calbasu does not breed in confined water but it breeds in shallow running waters. The movement of the breeders is slow in the spawning time thus many of them are killed before their spawning. Another serious handicap is that the fish suffers due to the change in the habitat or the ecological condition of the open water systems. For this reason, the induced breeding of this fish is subjective to carp breeding experts and hatchery operators' interests. The present investigation was conducted to ascertain the comparative efficacy of pituitary extracts and $\mathrm{DOM}+\mathrm{SGnRH}$ in the induced breeding of $L$. calbasu .

\section{Materials and methods \\ Brood collection and brood stock management}

For Induced breeding of Labeo calbasu, male and female brood fishes were collected from the Halda River and the Jamuna River. The broods were reared separately in the rectangular ponds with on average depth of $1.3 \mathrm{~m}$. The hatchery operators used Rotenone powder (30g/decimal) and netting to remove the predatory and unwanted species during pond preparation. Regular manuring with cow dung was done at 15 days interval at the rate of $5 \mathrm{~kg} /$ decimal and fertilization was done with urea and TSP at the rate of $200 \mathrm{~g} / \mathrm{decimal}$ and at the rate of100 g/decimal respectively to stimulate the growth of plankton. Liming was performed whenever necessary at the rate $1 \mathrm{~kg} /$ decimal. A special feed enriched with protein and vitamin E, was formulated which enhanced the gonad maturation in fishes. The ingredients of the feeds are fish meal $(18.43 \%)$, rice bran $(18.43 \%)$, wheat bran $(18.43 \%)$, soya bean meal $(18.43 \%)$, mustard oil cake (11.06\%), sesame oil cake $(11.06 \%)$, wheat flour $(3.69 \%)$, vitaminmineral premix $(0.46 \%)$ and vitamin $\mathrm{E}$ $(0.01 \%)$. Feed was applied at the rate of $4-5$ total body weight of fish two times daily. 
Abdus Salam Bhuiyan, Jesmin Akhter and Syeda Mushahida-Al-Noor / Our Nature (2013), 11(1): 17-24

During the experimentation temperature, $\mathrm{DO}, \mathrm{pH}$ of pond water were recorded between 26.5 and $31.1^{\circ} \mathrm{C}, 5.1$ and $6.5 \mathrm{ppm}$ and 6.7 and 7.4, respectively.

\section{Breeding plan}

For induced breeding of Labeo calbasu brood fishes were collected from the brood rearing pond of the hatchery complex at $1: 1$ ratio. Male and female broods are identified through secondary sexual characteristics of the fish. In this experiment three breeding trials with PG hormone and three breeding trials with DOM + SGnRH were performed, respectively as treatment 1 and treatment 2 to find out the comparative outcomes of these two inducing agents. Each trial was conducted by using 8 pairs of brood fishes.

\section{Collection and preparation of inducing agent extracts}

Locally available dehydrated carp pituitary glands (PG) and DOM + SGnRH were collected from the market in preserved condition in airtight vials used as inducing agents. An electronic balance (College HPTC 11, China) was used to measure the required amount of $\mathrm{PG}$ and $\mathrm{DOM}+\mathrm{SGnRH}$ by using the following formula.

Weight of inducing agent $(\mathrm{mg})=\frac{\mathrm{W}_{\mathrm{t}}-\mathrm{P}_{\mathrm{t}}}{1000}$

Where,

$\mathrm{W}_{\mathrm{t}}$ represents the total body weight $(\mathrm{g})$ of all the fishes to be injected and

$\mathrm{P}_{\mathrm{t}}$ represents the rate in mg inducing agents ( $\mathrm{PG}$ and $\mathrm{DOM}+\mathrm{SGnRH}$ ) to be injected per $\mathrm{kg}$ body weight under a particular treatment.

The weighed PG was transferred to a tissue homogenizer and thoroughly crushed. The crushed PG was then diluted with distilled water and was centrifuged by a centrifuge machine for precipitation. The following ratio of inducing agents and water were maintained in order to prepare the extracts. In case of treatment: PG: Water $=1$ mg: $2.5 \mathrm{ml}$. In case of treatment: DOM+ SGnRH: Water $=1: 2$.

\section{Conditioning of the broods}

Selected brood fishes were immediately carried to the hatchery and kept into the rectangular tank for about 6 hours. They were subjected to showering to induce the breeding condition. No feed was provided during the period of conditioning. The brood fishes were carefully handled to avoid injury and secondary infection.

\section{Inducing agent administration}

After preparation of inducing agent extracts, it was injected to brood fishes. Fishes were caught carefully by scoop net and kept in sponge. Inducing agents were then injected near the pectoral fin base. The amount of $\mathrm{PG}$ and DOM + SGnRH solution for each fish was determined before according to the body weight of the brood fishes. In this experiment, similar doses of PG extract were applied in different breeding trials as treatment 1 and similar doses of DOM + SGnRH were applied in different breeding trials as treatment 2. The doses of both solutions ( $\mathrm{PG}$ and $\mathrm{DOM}+\mathrm{SGnRH}$ ) are shown in table 1 and 2 . After administration of inducing agents, the brood fishes were again released in the circular spawning tank.

\section{Collection of fertilized eggs and transferring to hatching tank}

The fishes were removed from the rectangular tank when the ovulation was complete. Stripping was not required because the fertilization occurred in the circular tank. The fertilized eggs were 
Abdus Salam Bhuiyan, Jesmin Akhter and Syeda Mushahida-Al-Noor / Our Nature (2013), 11(1): 17-24

Table 1. Treatment 1 with PG for male and female brood of Labeo calbasu in three breeding trials.

\begin{tabular}{ccccccc}
\hline Trials & $\begin{array}{c}\text { Pairs of } \\
\text { brood } \\
\text { fish }\end{array}$ & $\begin{array}{c}\text { Weight of brood } \\
\text { fish }(\mathbf{k g})\end{array}$ & $\begin{array}{c}\text { Initial dose of PG } \\
\text { (mg/kg body weight of } \\
\text { fish) }\end{array}$ & $\begin{array}{c}\text { Time } \\
\text { interval }\end{array}$ & $\begin{array}{c}\text { Resolving dose of PG } \\
\text { (mg/kg body weight of } \\
\text { fish) }\end{array}$ & $\begin{array}{c}\text { Ovulation } \\
\text { (hours) }\end{array}$ \\
\hline 1 & 8 & $\begin{array}{c}\text { Female }=1.7 \pm 0.2 \\
\text { Male }=1.65 \pm 0.1\end{array}$ & Female $=1.5$ & 5.30 & $\begin{array}{c}\text { Female }=6 \\
\text { Male }=1.5\end{array}$ & 6.30 \\
\hline 2 & 8 & $\begin{array}{c}\text { Female }=1.8 \pm 0.1 \\
\text { Male }=1.6 \pm 0.1\end{array}$ & Female $=1.5$ & 5.15 & $\begin{array}{c}\text { Female }=6 \\
\text { Male }=1.5\end{array}$ & 6.15 \\
\hline 3 & 8 & $\begin{array}{c}\text { Female }=1.8 \pm 0.2 \\
\text { Male }=1.75 \pm 0.2\end{array}$ & Female $=1.5$ & 5 & $\begin{array}{l}\text { Female }=6 \\
\text { Male }=1.5\end{array}$ & 6 \\
\hline
\end{tabular}

Table 2. Treatment 2 with DOM+SGnRH for male and female brood of Labeo calbasu in three breeding trials.

\begin{tabular}{ccccc}
\hline Trials & $\begin{array}{c}\text { Pairs of } \\
\text { brood fish }\end{array}$ & Weight of brood fish (kg) & $\begin{array}{c}\text { Dose of DOM+SGnRH (mg/kg } \\
\text { body weight of fish) }\end{array}$ & $\begin{array}{c}\text { Ovulation } \\
\text { (hours) }\end{array}$ \\
\hline \multirow{2}{*}{1} & 8 & Female $=1.7 \pm 0.2$ & Female $=12$ \\
Male=3 & 8 \\
\hline 2 & 8 & $\begin{array}{c}\text { Memale }=1.8 \pm 0.1 \\
\text { Male }=1.65 \pm 0.2\end{array}$ & $\begin{array}{c}\text { Female }=12 \\
\text { Male }=3\end{array}$ & 6 \\
\hline \multirow{2}{*}{3} & 8 & $\begin{array}{c}\text { Female }=1.8 \pm 0.15 \\
\text { Male }=1.6 \pm 0.1\end{array}$ & $\begin{array}{c}\text { Female }=12 \\
\text { Male=3 }\end{array}$ & 7 \\
\hline
\end{tabular}

collected from the outlet of circular tank with net where the eggs came with water flow. The fertilized eggs were transferred into mini circular hatching tank with sufficient care. The mini circular tank was previously filled with filtered pond water to minimize the temperature difference and environmental shock. Continuous flow of water was maintained for aeration.

\section{Determination of fertilization and hatching} rates

For determination of fertilization and hatching rates approximately 100 eggs were placed in plastic bowls of 1.25 liter capacity with three replications each having water flow from porous PVC pipe and outlet facility. At first the number of fertilized and unfertilized eggs of each bowl was counted with naked eyes. After approximately 18-30 $\mathrm{h}$ of fertilization, it was observed that hatching was almost complete and the number of hatchlings in each bowl was counted. The following breeding parameters were recorded:

Ovulation rate $(\%)=$ No. of fish ovulated

$\overline{\text { Total no. of female fish injected }} \times 100$

Fertilization rate $(\%)=$ No. of fertilized eggs

$\overline{\text { Total no. of eggs (fertilized }+ \text { unfertilized) }} \times 100$

Hatching rate $(\%)=\frac{\text { No. of eggs hatched }}{\text { Total no. of fertilized eggs }} \times 100$

\section{Results}

Ovulation rate

The average ovulation rate of three breeding trials in case of treatment 1 and 2 are shown respectively in table 3 and 4 . In treatment 1 , mean ovulation rate was $(100 \%)$ recorded for three trials. On the contrary, in treatment 2 , the mean ovulation rate was $(83.34 \%)$ 
Abdus Salam Bhuiyan, Jesmin Akhter and Syeda Mushahida-Al-Noor / Our Nature (2013), 11(1): $17-24$

recorded for three trials. The highest ovulation rate $(100 \%)$ was found in all trials of treatment 1 . The lowest ovulation rate $(75 \%)$ was found in trial I for treatment 2 (Fig. 1).

Table 3. Breeding performance of kalibaus (Labeo calbasu) with different doses of PG hormone in different breeding trials

\begin{tabular}{cccc}
\hline Trials & $\begin{array}{c}\text { Ovulation } \\
\text { rate (\%) }\end{array}$ & $\begin{array}{c}\text { Fertilization } \\
\text { rate (\%) }\end{array}$ & $\begin{array}{c}\text { Hatching } \\
\text { rate (\%) }\end{array}$ \\
\hline 1 & $100 \pm 0.0$ & $75 \pm 0.73$ & $72.5 \pm 0.56$ \\
2 & $100 \pm 0.0$ & $77 \pm 0.73$ & $75 \pm 0.73$ \\
3 & $100 \pm 0.0$ & $80 \pm 0.59$ & $76 \pm 0.73$ \\
\hline
\end{tabular}

Table 4. Breeding performance of kalibaus (Labeo calbasu) with different doses of $\mathrm{DOM}+\mathrm{SGnRH}$ in different breeding trials

\begin{tabular}{cccc}
\hline Trials & $\begin{array}{c}\text { Ovulation } \\
\text { rate (\%) }\end{array}$ & $\begin{array}{c}\text { Fertilization } \\
\text { rate (\%) }\end{array}$ & $\begin{array}{c}\text { Hatching } \\
\text { rate (\%) }\end{array}$ \\
\hline 1 & $75 \pm 0.73$ & $62.5 \pm 0.84$ & $58 \pm 0.98$ \\
2 & $87.5 \pm 0.35$ & $64 \pm 0.56$ & $60 \pm 1.38$ \\
3 & $87.5 \pm 0.35$ & $65 \pm 0.70$ & $61 \pm 0.43$ \\
\hline
\end{tabular}

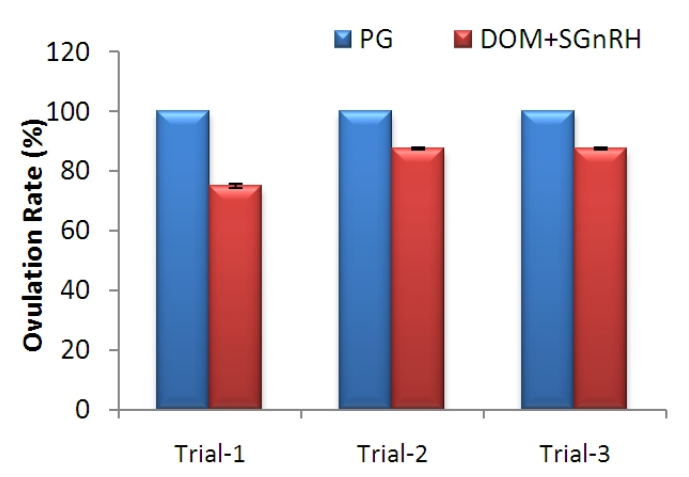

Figure 1. Ovulation rate (\%) of Labeo calbasu in different breeding trials.

\section{Fertilization rate}

In case of treatment 1 and 2, the average fertilization rates of three trials are shown respectively in table 3 and 4 . In treatment 1 the mean fertilization rate was $77.34 \%$ recorded for three trials. On the other hand, in case of treatment2 the mean rate of fertilization was $63.83 \%$ recorded for three trials. The highest fertilization rate was $80 \%$ recorded in trials 3 followed by trial 1 and 2 ( 75 and $77 \%$, respectively) for treatment 1 . The lowest fertilization rate was $62.5 \%$ recorded in trial 2 for treatment 2 (Fig. 2).

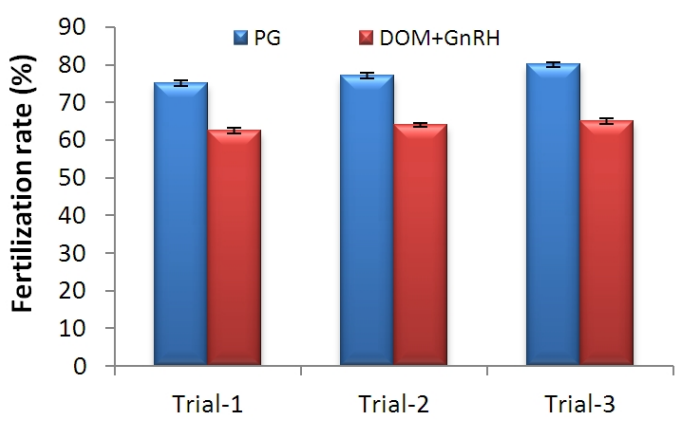

Figure 2. Fertilization rate (\%) of Labeo calbasu in different breeding trials.

\section{Hatching rate}

During the experimentation on Labeo calbasu the average hatching rate of three breeding trials for both treatments are shown in the table 3 and 4 . The mean rate of fertilization in treatment 1 was recorded $74.5 \%$ for three trials and the mean rate of fertilization in treatment 2 was recorded $59.66 \%$. The highest hatching rate $(76 \%)$ was found in trial 3 of treatment 1 . The lowest hatching rate was $58 \%$ recorded in trial 1 for treatment 2 (Fig. 3).

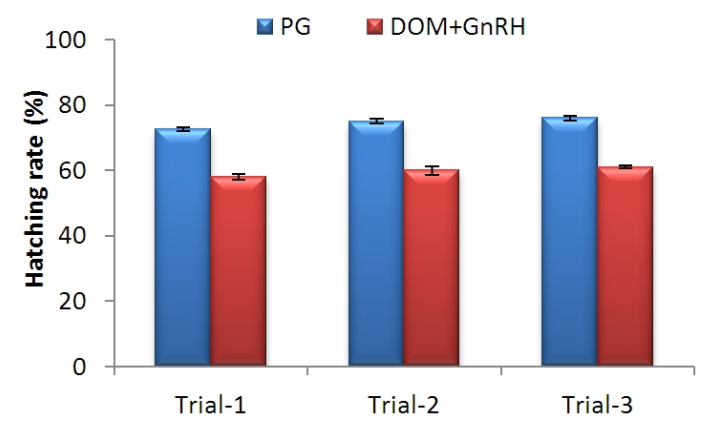

Figure 3. Hatching rate (\%) Labeo calbasu in different breeding trials. 
Abdus Salam Bhuiyan, Jesmin Akhter and Syeda Mushahida-Al-Noor / Our Nature (2013), 11(1): $17-24$

\section{Discussion}

Proper care of brood stock is very important for assuring good production of eggs, hatchlings, fry and fingerlings (Piper et al., 1982; Alam and Bhuiyan, 1999). The daily and seasonal rates of feeding of brood stock diets have direct effects on fecundity and egg size (Jones and Bromage, 1987). After successful completion of brood stock management with balanced feed comprising adequate amount of protein, lipid, and carbohydrate, especially enriched with vitamin-E the fish $L$. calbasu attained gonadal maturity in late April. In the present study, it was found that L. calbasu bred in April and August. The peak breeding season was May and June and it continued till August. According to Jhingran (1982) the breeding season of the Indian major carps generally starts from April and continues to August, with an optimum period between May and June. Ibrahim et al. (1968) reported that temperature ranging from $26.5^{\circ}$ to $35.0^{\circ} \mathrm{C}$ is appropriate for spawning of major carps. Breeding of L. calbasu was performed at an ambient temperature of $26.5^{\circ}$ to $31.1^{\circ} \mathrm{C}$. Uses of feed with vitamin mineral premix have some positive effect for the maturation of fishes. Selectively, spawning success, fertilization and hatching rate. Spawning performance of the reared broods indicated that the spawners were at their optimal breeding condition. This might be due to good management practices of brood stock which elongated their breeding season in artificial condition.

In this experiment the induced breeding trials were done with pituitary gland $(\mathrm{PG})$ extract and DOM + SGnRH on the as inducing of $L$. calbasu. The operators achieved mean fertilization and hatching rate ( 73.05 and $60.43 \%$, respectively) by using an initial and a resolving dose of 2.03.0 and $5.0-7.0 \mathrm{mg} / \mathrm{PG} / \mathrm{kg}$ body weight for female. They administered a single dose of $2.0 \mathrm{mg} \mathrm{PG} / \mathrm{kg}$ body weight for male. In this experiment best fertilization and hatching rate ( 80 and $76 \%$, respectively) were gained by using PG in trial 3 for treatment 1 . In this study trial 3 showed best result since brood fishes were fully matured. The result in consideration of fertilization and hatching rate were lowest in trial 1 for synthetic hormone $(\mathrm{DOM}+\mathrm{SGnRH})$. But in this experiment ovulation occurred within 6 to $6.30 \mathrm{hrs}$ after resolving dose to females at the temperature from $27^{\circ}$ to $31^{\circ} \mathrm{C}$. Khan and Mukhapadhay (1975) pointed out that the success of entire operation of induced breeding depends largely on the proper selection of brood fishes, which had proved very true in the present experiment. Accomplishment of successful spawning depends on selection of suitable recipient fish at the proper stages of ovarian development and creation of congenial spawning conditions (Nash and Shehadesh, 1980).

Singh et al. (2000) maintained two year old stocks of catla, rui in two 0.08 ha ponds at stocking density of 1500-1750 $\mathrm{kg} / \mathrm{ha}$. Rearing of catla and rui on a $5 \mathrm{~mm}$ pellet diet consisting of fish meal $10 \%$, ground nut oilcake $35 \%$, soyabean oil cake $20 \%$, wheat flour $10 \%$, rice bran $24.8 \%$, trace mineral mix $0.1 \%$ and vitamin mix $0.1 \%$ at $2-3 \%$ of body weight gave very good maturity. Administration of ovaprim in catla (females $0.4-0.5 \mathrm{ml} / \mathrm{kg}$, males 0.2 $\mathrm{ml} / \mathrm{kg}$ ) and rui (females 0.3-0.4 $\mathrm{ml} / \mathrm{kg}$, males $0.1-0.2 \mathrm{ml} / \mathrm{kg}$ ) produced $100 \%$ spawning success in both species, except in one case where it was partial in catla. They also found that 3 sets of Labeo rohita 
Abdus Salam Bhuiyan, Jesmin Akhter and Syeda Mushahida-Al-Noor / Our Nature (2013), 11(1): 17-24

yielded 101 litres of fertilized eggs with 90 $95 \%$ fertilization showing excellent performance of brood fish.

Bhuiyan and Aktar (2011) have studied the effect of two inducing agents PG and $\mathrm{HCG}$ on the induced breeding of major carps. In this experiment, in first dose 1-4 $\mathrm{mg} / \mathrm{kg}$ PG and 150-500 IU/kg HCG has been injected in female broods. In second dose, $\mathrm{PG}$ of $4-8 \mathrm{mg} / \mathrm{kg}$ in female broods and $4-10 \mathrm{mg} / \mathrm{kg}$ in male broods has been injected. The incubation period and hatching rate in different fish species varied from $10-72 \mathrm{~h}$ and $55-80 \%$, respectively.

Minar et al. (2012) have studied the effect of two inducing agents PG and HCG on the induced breeding of major carps and Exotic carps. Two types of hormone injections like PG (pituitary gland) and HCG (human chorionic gonadotropin) were used for induced spawning. The rate of $1 \mathrm{st}$ doses of injections of PG were from 1 to 4 $\mathrm{mg} / \mathrm{kg}$ and $\mathrm{HCG}$ from 150 to $500 \mathrm{IU} / \mathrm{kg}$ and the rate of second doses of injections of PG for native and exotic species were from 4 to $8 \mathrm{mg} / \mathrm{kg}$ and 4 to $10 \mathrm{mg} / \mathrm{kg}$, respectively. The ovulation period and hatching rate in different fish species varied from 1.5 to $6 \mathrm{~h}$ and 47 to $86 \%$, respectively.

\section{Conclusion}

Though L. calbasu is now a threatened species of Bangladesh, culture will be the effective measure to conserve the species. The quality seed production technology of the species is the prerequisite of development of culture technique. With this aim, to develop the brood stock management, induced breeding, measuring doses of inducing agents for $L$. calbasu the present study was undertaken. The findings will prove fruitful to develop the induced breeding techniques of $L$. calbasu to supply adequate amount of seeds to the farmers. From the present investigation, it can be predicted that induced breeding of $L$. calbasu through DOM $+\mathrm{SnRH}$ will accelerate the induced breeding process, reduce ovulation time and cost-benefit to the hatchery operators. Though hypophy-sation is widely practiced in the hatcheries of Bangladesh but DOM + SnRH can be established as an important alternative inducing agent for PG and the development of induced breeding of fishes.

\section{References}

Ahmed, M.K. 1983. Induced breeding of Indian major carps, Chinese carps and Catfish. Freshwater Fish Research Station Chandpur, Bangladesh. pp. 44-52.

Alam, A.K.M.A. 1983. Low cost hatchery. Adam News 10(L): 27-33.

Alam, M.M. and A.S. Bhuiyan 1999. Determination of the optimum PG dose for inducing spawning of Labeo rohita (Hamilton, 1822). Univ. J. Zool. Raj. Univ. 18: 103-108.

Ali, M.H. 1967. Induced breeding of major carps in ponds by pituitary hormone injection. Agric. Inform. Serv., Dhaka. pp. 23-26.

Ali, M.L. 1998. Fishery resources development and management technique. Fish week 98 compendium, Department of Fisheries, Ministry of Fisheries and Livestock, Government of the Peoples Republic of Bangladesh, Dhaka. pp. 110.

Bhuiyan, A.S. and N. Aktar 2011. Observation on the induced practices in the hatcheries of Rajshahi District of Bangladesh, J. Life Earth Sci. 6: 6568.

Bhuiyan, A.S., A.S.M. Musa and M.K. Islam 2008. Hatchery management in Bangladesh. Aquaculture Asia Magazine, Genetics and Biodivesity, April-June. pp. 20-24.

Bhuiyan, A.S., M.K. Islam and Z. Tanjeena 2007. Induced spawning of Puntius gonionotus (Bleeker). Bangladesh J. Zool. 35(2): 245-249.

Brzuska, E. 2005. Artificial spawning of carp (Cyprinus carpio L.), differences between females of Polish strain 6 and Hungarian strain 
Abdus Salam Bhuiyan, Jesmin Akhter and Syeda Mushahida-Al-Noor / Our Nature (2013), 11(1): $17-24$

W treated with carp pituitary homogenate, Ovopel or Dagin. Aquaculture Resarch 36: $1015-1025$

Haque, K.A. 1975. Some observations on the induced spawning of major carps by pituitary hormone injection, Freshwater fish. Res. Sta. Chandpur. Bull. 1: 19-33.

Ibrahim, K.H., R.M. Bhowmik and G.C. Panicher 1968. Observation of the role of water temperature in induced breeding of Indian carp. J. Inland Fish. Soc. 2: 128-131.

Islam, M.Z. and A.Q. Chowdhury 1976. Induced spawning of major carps for commercial production of fry for fish seed in Bangladesh. Bangladesh J. Zool. 4(2): 51-61.

IUCN. 2000. Redbook of threatened fishes of Bangladesh. IUCN Bangladesh, The World Conservation Union. 71p.

Jhingran, V.G. 1982. Fish and fisheries of India. Hindustan Publishing Corporation, Delhi, India.

Jones, J. and N. Bromage 1987. The influence of ration size on the reproductive performance of female rainbow trout. In Reproductive physiology of fish (Eds. I.L. Crim and J. Walsh). 22p.

Khan, H.A. and S.K. Mukhapadhay 1975. Production of stocking material of some air breathing fishes by hypophysation. J. Inland Fish. Soc. India 7: 156-161.

Krejszeff, S., D. Kucharczyk, K. Kupren, K. Targońska, A. Mamcarz, R. Kujawa, Z. Kaczkowski and S. Ratajski 2008. Reproduction of chub, Leuciscus cephalus L., under controlled conditions. Aquaculture Resarch 39: 907-912.

Kucharczyk, D., K. Targońska, P. Hliwa, P. Gomułka, M. Kwiatkowski, S. Krejszeff and J. Perkowski 2008. Reproductive parameters of common carp (Cyprinus carpio L.) spawners during natural season and out-of-season spawning. Reproductive biology 8(3): 285-289.

Kucharczyk, D., R. Kujawa, A. Mamcarz, K. Targońska-Dietrich, E. Wyszomirska, J. Glogowski, I. Babiak and T. Szabo 2005. Induced spawning in bream (Abramis brama L.) using pellets containing LH-RH. Czech journal of animal science 50(3): 89-95.

Marte, C.L. 1989. Hormone induced spawning of cultured tropical finfish. Advanced Tropical Aquaculture 9: 519-539.
Minar, M.H., M.D. Shamsuddin, M.G.U. Bablu and S.I. Bhuiyan 2012. Induced spawning practices of different fishes in the hatcheries of Barisal district of Bangladesh. Trends in Fisheries Research 1(2): 14-17.

Montchowui, E., C.A. Bonou, P. Laleye, J.C. Philippart and P. Poncin 2011. Successful artificial reproduction of the African carp: Labeo parvus Boulenger,(Pisces: Cyprinidae). Interna. J. Fish. Aquacul. 3(3): 36-41.

Nash, C.E. and Z.H. Shehadesh 1980. Review of Breeding and Propagation Techniques of Grey Mullet, Mugil cephallus L. ICLARM Studies 3, ICLARM, Manila, Philippines. 87p.

Peter, R.E., H.R. Lin and G. Van der Kraak 1988. Induced ovulation and spawning of cultured freshwater fish in China. Advances in application of GnRH analogues and dopamine antagonists. Aquaculture 74: 1-10.

Piper, R.G., I.B. Melweing, L.E. Orme, J.P. Craren, L.G. Fowler and J.R. Leonard 1982. Fish hatchery management. US Department of Interior, Fish and Wildlife Service, Washington DC. pp. 131-199.

Sharma, A.P. and V.K. Singh 2002. Induced breeding responses of Indian major carps. Vi. Labeo rohita, Catla catla and Cirrhina mrigala using ovaprim and carp pituitary extract. Indian $J$. Animal Sci. 72(4): 351-354.

Singh, B.N., R.C. Das, A.K. Sahu and A.K. Pandey 2000. Balanced diet for the brood stock Catla catla and Labeo rohita and induced breeding performance using ovaprim. J. Advanced Zoology, Central Inst. Freshwater Aquaculture, India 21(2): 92-97.

Targońska, K., D. Żarski and D. Kucharczyk 2008. A review of the artificial reproduction of asp, Aspius aspius (L.) and nase, Chondrostoma nasus (L.). Archives of Polish Fisheries 16(4): 341-354.

Żarski, D., D. Kucharczyk, K. Targońska, M. Jamróz, S. Krejszeff and A. Mamcarz 2009. Application of Ovopel, Ovaprim and their combination in artificial reproduction of two rheophilic cyprinid fishes. Polish journal of natural science 24: 235 244. 